\title{
Population biology of the hermit crab Petrochirus diogenes (Linnaeus) (Crustacea, Decapoda) in Southern Brazil
}

\author{
Alexander Turra ${ }^{1}$ \\ Joaquim Olinto Branco ${ }^{2}$ \\ Flávio Xavier Souto ${ }^{2}$
}

\begin{abstract}
The aim of this study was to provide information on the biology of a subtropical population of the hermit crab Petrochirus diogenes focusing size structure, sex ratio, reproductive period and morphometric relationships. Monthly samples were done between January and December 1995 at Armação of Itapocoroy, Penha, southern Brazil, using two over-trawls in depths from 6.0 to $10.0 \mathrm{~m}$. A total of 126 individuals were collected. Overall sex ratio did not differ from 1:1. When the sex ratio was analyzed for each size class, it was skewed for females in the smallest size classes while males outnumbered females in the largest ones. The mean size (cephalothoracic length) of $P$. diogenes was $30.61 \pm 12.52 \mathrm{~mm}$ and the size structure of this population was skewed to the right. Males were on average larger and heavier than both ovigerous and non-ovigerous females, which, in turn, showed similar sizes and weights. The ovigerous females represented $61 \%$ of all females and occurred from January to April and in September and December. The relationship of cephalothoracic length and both cephalothoracic width and crab weight were isometric. Both crab size and weight showed a negative allometry with shell weight, indicating that larger/heavier crabs use proportionally lighter shells than small-sized ones.

KEY WORDS. Size distribution, population structure, sex ratio, morphometric relationships, reproductive activity
\end{abstract}

Hermit crabs are a group of crustaceans adapted to live inside gastropod shells. They are well succeeded in many environments, from terrestrial and semiterrestrial habitats to depths up to 600m (FOREST \& SAINT LAURENT 1967). They are important components of macro-invertebrate assemblages, both in intertidal and subtidal areas around the world (BRANCO et al. 1998; MANJÓN-CABEZA \& GARCía-Raso 1998; Martinez-IGlesias \& García-Raso 1999; Mello 1999).

The importance of hermit crabs and their particular shell utilization behavior stimulated numerous studies (see HAZLETT 1981 for a review). In particular, studies on the population structure of hermit crabs are recent (see BERTINI \& FRANSOZO 2000a; TURRA \& LEITE 2000 for reviews) and showed that hermit crabs may have continuous or seasonal reproduction and may exhibit sexual dimorphism with males being on average larger than females. Sex ratio is generally skewed for females, especially in the smallest or intermediate size classes (BERTINI \& FRANSOZO 2000a).

1) Curso de Pós-graduação em Ecologia, Departamento de Zoologia, Intituto de Biologia, Unicamp. 13080-970 Campinas, São Paulo, Brasil. E-mail: turra@unicamp.br

2) Centro de Ciências Tecnológicas da Terra e do Mar, UNIVALI. Caixa Postal 360, 88301-970 Itajaí, Santa Catarina, Brasil. E-mail: branco@cttmar.univali.br 
Petrochirus diogenes is a large hermit crab species (see GASPARINI \& FLOETER 1999) and is a very common littoral hermit crab in Brazilian waters (BRANCO et al. 1998), occurring from the shallow sublittoral to depths up to $130 \mathrm{~m}$ (MELLO 1999). This species has a wide geographical distribution in the Occidental Atlantic, being reported from Eastern USA to Uruguai (RIEGER 1997). The population biology (BERTINI \& FRANSOZO 1999a, 2000a), the shell utilization pattern (KELLOGG 1977; BERTINI \& FRANSOZO 2000b) and the relative growth (BERTINI \& FRANSOZO 1999b) of a tropical population of Petrochirus diogenes was previously studied. Other studies focused on larval development (PROVENZANO 1968) and records of maximum size (GASPARINI \& FLOETER 1999).

The aim of this study was to provide information on the population biology of the giant hermit crab Petrochirus diogenes from a subtropical region. The size structure and the reproductive period of this population is described as well as the sex ratio and its relationship with crab size. Hermit crab morphometric relationships were estimated based on cephalothoracic length and width and on crab weight. The relationships between crab and shell dimensions were also described.

\section{MATERIAL AND METHODS}

This study was conducted between January and December 1995 at Armação of Itapocoroy, Penha, Santa Catarina, Brazil (26 $46^{\prime} \mathrm{S}, 48^{\circ} 36^{\prime} \mathrm{W}$ and $26^{\circ} 47^{\prime} \mathrm{S}, 48^{\circ}$ $\left.37^{\prime} \mathrm{W}\right)$. The bottom of this area is composed by sand in the shallowest parts and by biodetritic sediment in the deepest ones. Monthly samples were done in three periods (morning, afternoon, and evening) using two over-trawls with $6 \mathrm{~m}$ at the opening, $30.00 \mathrm{~mm}$ mesh at the outer part and $20.00 \mathrm{~mm}$ mesh in the bag. The sediment was trawled in depths from 6.0 to $10.0 \mathrm{~m}$ during 30 minutes at constant speed of 2 knots. The water temperature was also measured monthly in these three periods.

The individuals of Petrochirus diogenes were removed from their shells and then measured (cephalothoracic length and width, $\mathrm{mm}$ ) and weighed (g). The shells were also weighed (g). The sex of the crabs as well as the presence of ovigerous females was recorded. Monthly means of density and water temperature were calculated using morning, afternoon and evening samples as replicates. The population sex ratio was compared to $1: 1$ with the log-likelihood G test (ZAR 1996). The size and weight of males, ovigerous females and non-ovigerous females was compared through the non-parametric Kruskal-Wallis test followed by a non-parametric Tukey-type post-hoc test (ZAR 1996). Power functions $\left(y=a x^{b}\right)$ were fitted to estimate the relationships of cephalothoracic length with cephalothoracic width and crab weight. This function was also fitted for the relationship between shell weight and both cephalothoracic length and crab weight. The Student $t$ test was used to test the null hypothesis of isometry ( $b=1$ for linear relationships, i.e., length vs. length, or $b=3$ for exponential relationships, i.e., length vs. weight) for these relationships. All tests were conducted with the significant level fixed at 0.05 . Mean \pm standard error is presented through the text. Once the cephalothoracic length instead of the shield length was measured in the present study, a conversion factor was used to compare the size distribution of this population of $P$. diogenes with previous studies. 


\section{RESULTS}

Petrochirus diogenes was collected year round with a higher abundance in the summer months (December to March) and a peak in February (Fig. 1). The number of individuals decreased after this period and stayed low until November. The temperature varied from $18.7^{\circ} \mathrm{C}$ to $26.5^{\circ} \mathrm{C}$ during the sampling period but the highest temperatures $\left(25.0^{\circ} \mathrm{C}\right.$ to $\left.26.5^{\circ} \mathrm{C}\right)$ were recorded from November to February (Fig. 1). Then, the temperature decreased throughout winter and reached its minimum value in September.

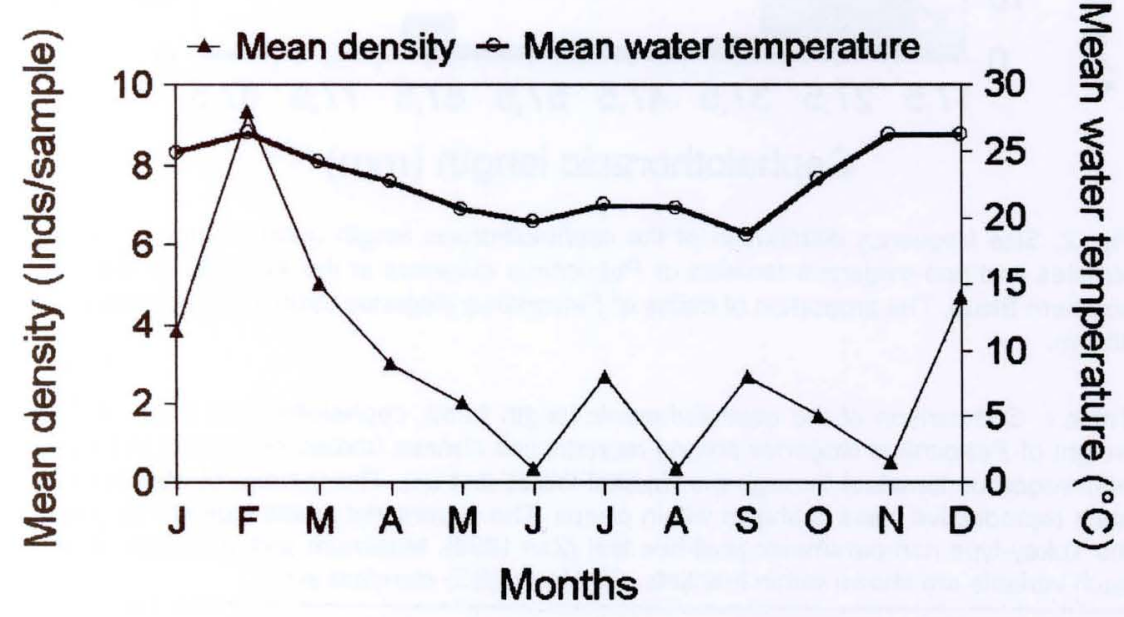

Fig. 1. Annual variation in mean density (Inds/sample) of Petrochirus diogenes and in mean water temperature $\left({ }^{\circ} \mathrm{C}\right)$ at the Armação of Itapocoroy, southern Brazil. (data from morning, afternoon, and evening samples were averaged to generate monthly means).

A total of 126 individuals were collected during the sampling period, with 66 females and 60 males. The mean size of $P$. diogenes was $30.61 \pm 13.52 \mathrm{~mm}$ and the size structure of this population was skewed to the right (Fig. 2). The individuals were concentrated between 20.00 and $30.00 \mathrm{~mm}$ size classes, but a slight increase was evident at the $67.50 \mathrm{~mm}$ size class. Males, ovigerous females and non-ovigerous females differed in size (cephalothoracic length and width) and weight (Tab. I). Males were on average larger and heavier than both ovigerous and non-ovigerous females, which, in turn, showed similar sizes and weights. The sex ratio did not differ from $1: 1(\mathrm{G}=0.29 \mathrm{df}=1, \mathrm{p}<0.001)$ when all these individuals were considered. When the sex ratio was analyzed for each size class, it became evident that sex ratio was skewed for females in the smallest size classes while males outnumbered females in the largest ones (Fig. 2).

The ovigerous females represented $61 \%$ of all females in the whole studied period. They occurred irregularly over the year from January to April and in September and December with a peak in March (Fig. 3). The smallest ovigerous female was $19.00 \mathrm{~mm}$. 


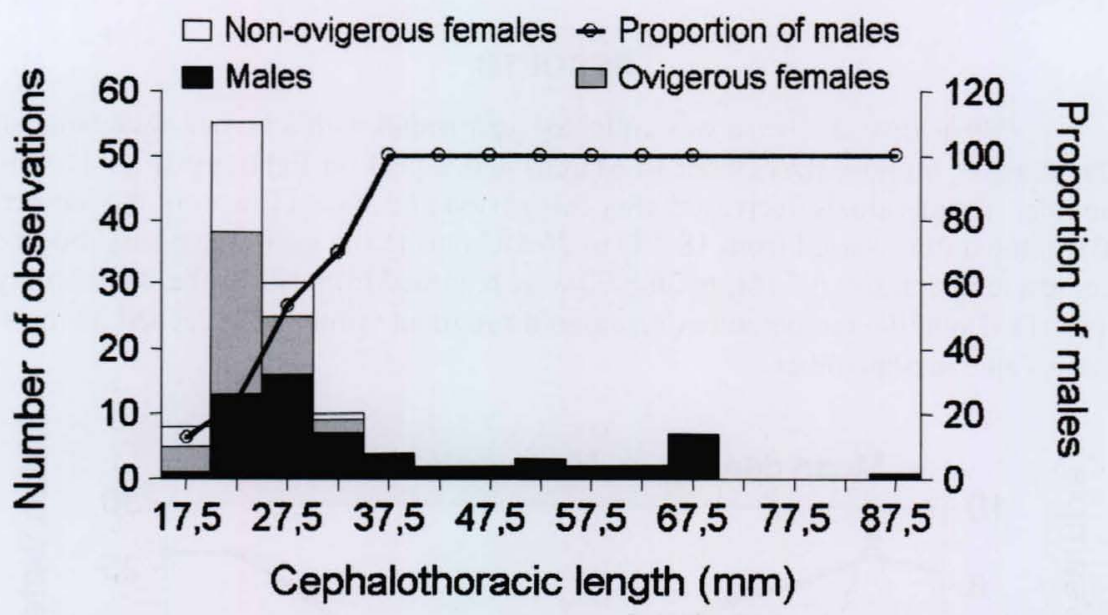

Fig. 2. Size frequency distribution of the cephalothoracic length $(\mathrm{mm})$ of males, ovigerous females and non-ovigerous females of Petrochirus diogenes at the Armação of Itapocoroy, southern Brazil. The proportion of males of Petrochirus diogenes through size classes is also shown.

Table I. Comparison of the cephalothoracic length $(\mathrm{mm})$, cephalothoracic width $(\mathrm{mm})$ and weight of Petrochirus diogenes among reproductive classes (males, ovigerous females and non-ovigerous females) through the Kruskal-Wallis test $(\mathrm{H})$. The number of observations in each reproductive class is shown within clasps. The superscript labels indicate the result of the Tukey-type non-parametric post-hoc test (ZAR 1996). Maximum and minimum values for each variable are shown within brackets. (X) Mean, (SE) standard error.

\begin{tabular}{|c|c|c|c|c|c|}
\hline \multirow{2}{*}{ Parameter } & Non-ovigerous females [26] & Ovigerous Females [40] & Males [60] & \multirow{2}{*}{$\mathrm{H}$} & \multirow{2}{*}{$p$} \\
\hline & $x \pm S E$ & $x \pm S E$ & $x \pm S E$ & & \\
\hline Cephalothoracic length $(\mathrm{mm})$ & $\begin{array}{l}24.13 \pm 0.62^{\mathrm{a}} \\
(20.00-32.00)\end{array}$ & $\begin{array}{l}24.05 \pm 0.53^{a} \\
(19.00-35.00)\end{array}$ & $\begin{array}{c}37.90 \pm 2.15^{b} \\
(19.00-86.00)\end{array}$ & 38.490 & $<0.001$ \\
\hline Cephalothoracic width (mm) & $\begin{array}{l}16.92 \pm 0.47^{a} \\
(14.00-22.00)\end{array}$ & $\begin{array}{l}17.33 \pm 0.43^{a} \\
(13.00-25.00)\end{array}$ & $\begin{array}{c}26.72 \pm 1.59^{b} \\
(9.00-64.00)\end{array}$ & 34.134 & $<0.001$ \\
\hline Crab weight $(\mathrm{g})$ & $\begin{array}{l}15.61 \pm 1.41^{\mathrm{a}} \\
(7.68-38.38)\end{array}$ & $\begin{array}{c}21.33 \pm 1.77^{a} \\
(8.45-59.43)\end{array}$ & $\begin{array}{l}97.64 \pm 17.49^{b} \\
(7.00-792.00)\end{array}$ & 32.025 & $<0.001$ \\
\hline
\end{tabular}

The cephalothoracic length and width of the crabs were strongly and isometrically correlated (Student t test, $\mathrm{t}=-1.31 ; \mathrm{df}=124 ; \mathrm{ns}$ ) (Fig. 4 ) as well as cephalothoracic length and crab weight (Student t test, $\mathrm{t}=24.34 ; \mathrm{df}=124 ; \mathrm{p}<0.001$ ). Negative allometry was recorded in the relationships between cephalothoracic length and shell weight and between crab weight and shell weight (Student t test, $\mathrm{t}=-9.12 ; \mathrm{df}=124$; $\mathrm{p}<0.001$ and $\mathrm{t}=-10.54 ; \mathrm{df}=124, \mathrm{p}<0.001$, respectively) (Fig. 4).

\section{DISCUSSION}

Temporal variation in abundance of individuals of a given species in a given site may be caused by migrations or mass mortalities associated to harsh environmental conditions in some periods of the year. In the warmer waters of 
- Ovigerous females $\square$ Non-ovigerous females $\square$ Males

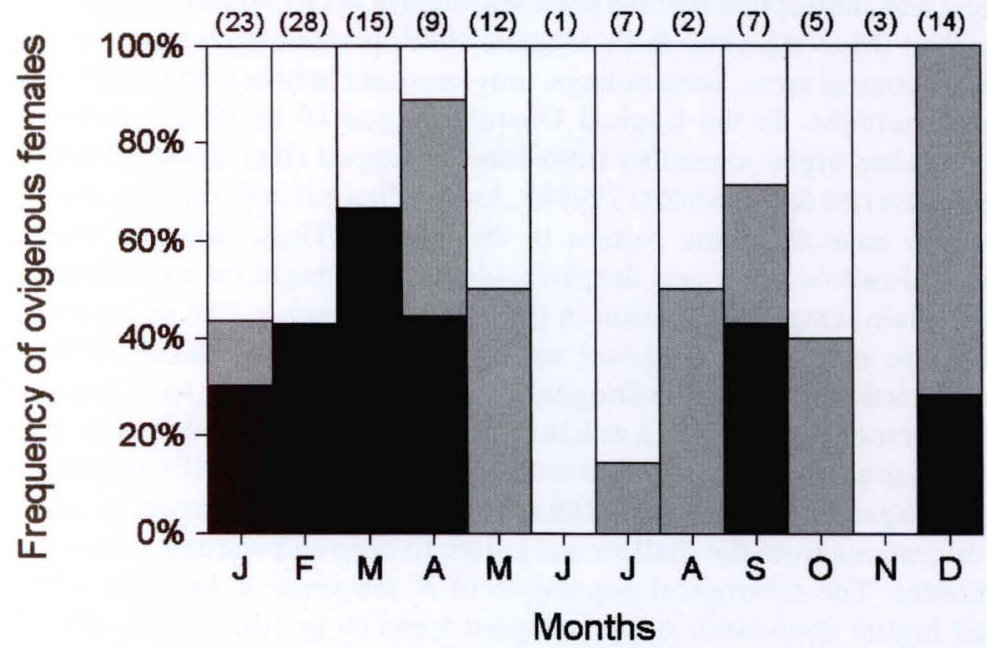

Fig. 3. Reproductive activity of Petrochirus diogenes indicated by the frequency of ovigerous females through the year at the Armação of Itapocoroy, southern Brazil. Monthly total number of individuals is shown within brackets.
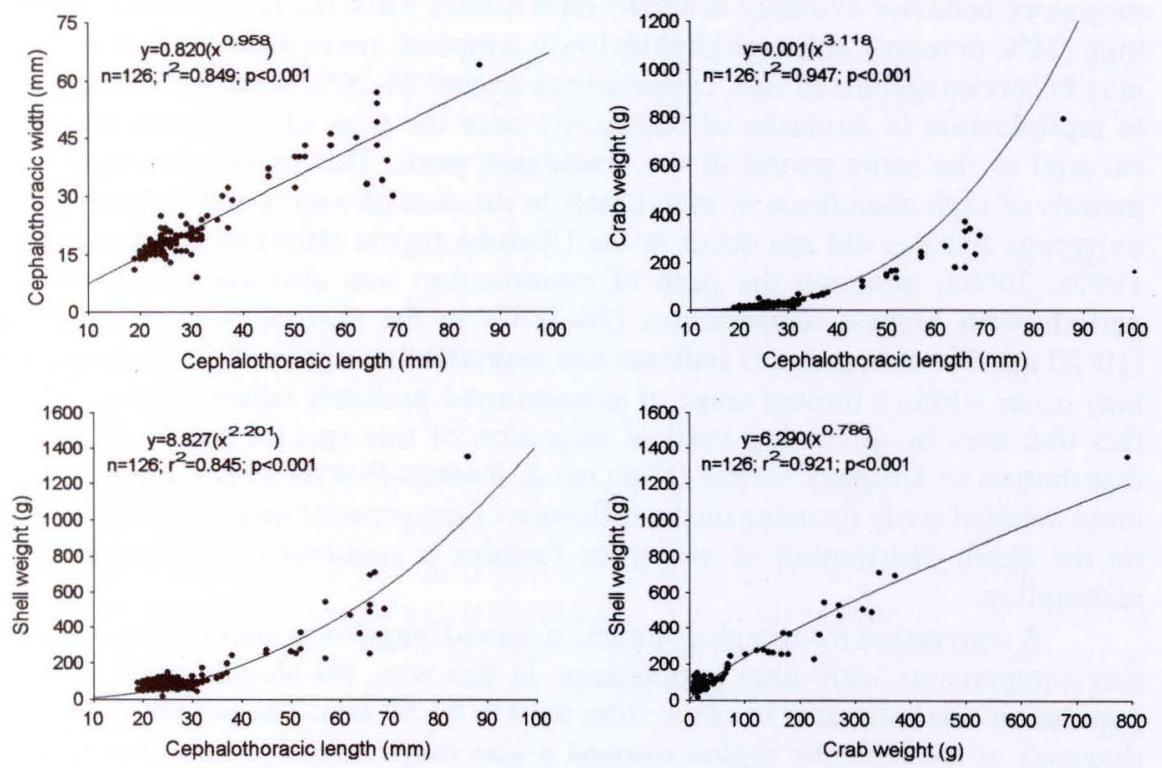

Fig. 4. Morphometric relationships of Petrochirus diogenes showing the relationships between cephalothoracic length and width and between cephalothoracic length and crab weight (upper). The relationships between cephalothoracic length and shell weight and between crab and shell weights were also estimated (lower). 
the tropical and subtropical regions such seasonality in environmental parameters is not marked (MANTELATTO \& FRANSOZO 1999; present study) but the temperature in the coastal areas, such as bays, may oscillate between 25 to $28^{\circ} \mathrm{C}$ during the summer months. In the tropical Ubatuba region ( 5 to $20 \mathrm{~m}$ ), Petrochirus diogenes reaches higher densities from June to August (NEGREIROS-FRANSOZO et al. 1997; BERTINI \& FRANSOZO 1999b). Another hermit crab species, Dardanus insignis, also have the same pattern in this region. Thus, seasonal migration between shallower/warmer and deeper/colder waters might be a possible hypothesis to explain temporal variation in these tropical hermit crab populations. In fact, there are records $P$. diogenes up to $130 \mathrm{~m}$ depth (MELlo 1999). The temperate intertidal hermit crab Diogenes nitidimanus migrates to subtidal areas in the summer months (ASAKURA \& KIKUCHI 1984; ASAKURA 1987). The tropical intertidal and shallow subtidal hermit crabs Clibanarius vittatus (FOTHERINGHAM 1975) and Pagurus longicarpus (REBACH 1978, 1981) also undergo seasonal vertical migrations from the shallow and colder to deep and warmer waters during winter months. The subtropical population of $P$. diogenes at Armação of Itapocoroy had higher abundance in the sampled areas (6 to $10 \mathrm{~m}$ depth) during the warmer months. The water temperature in this area during this period of the year ( 25 to $26^{\circ} \mathrm{C}$ ) is higher than the temperature in the winter months in the Ubatuba coastal region ( 19 to $23^{\circ} \mathrm{C}$; BERTINI \& FRANSOZO 1999a) but lower than those in the summer months. These data may evidence that $P$. diogenes have a vertical migratory behavior avoiding shallow warm waters when the temperature is very high $\left(28^{\circ} \mathrm{C}\right.$ or more), although slightly lower temperatures in these shallow waters may be advantageous. In fact, temperatures around $25-26^{\circ} \mathrm{C}$ seem to be adequate to reproduction in Armação of Itapocoroy once the peak of ovigerous females occured in the same period of the abundance peak. This association between periods of high abundance of individuals in the coastal waters and frequency of ovigerous females did not occur in the Ubatuba region (BERTINI \& FRANSOZO 1999a, 2000a) although the peak of reproduction was also associated to the periods with highest temperatures $\left(26-28^{\circ} \mathrm{C}\right)$ in the shallow waters sampled $(10-20 \mathrm{~m})$. These arguments indicate that reproductive optimum in $P$. diogenes may occur within a limited range of temperatures, probably between 24 to $26^{\circ} \mathrm{C}$, fact that may be governing vertical migration of this species and limiting its distribution to Uruguay waters (COELHO \& RAMOS-PORTO 1987). However, a more detailed study focusing on the influence of temperature on reproduction and on the depth distribution of ovigerous females is required to strengthen this assumption.

A conversion from cephalotoracic to shield length was employed to enable size comparisons with other populations. In this way, the shield length of this population was estimated to range from 9.10 to $41.30 \mathrm{~mm}$. The population of $P$. diogenes at the Ubatuba region showed a size range slightly skewed to lower values ( 5.40 to $40.00 \mathrm{~mm}$; BERTINI \& FRANSOZO 1999b), indicating the presence of smaller individuals than collected in Armação of Itapocoroy. This was probably due to the smaller mesh size used by BERTINI \& FRANSOZO $(12 \mathrm{~mm}$ mesh size with $10 \mathrm{~mm}$ at the cod end, 1999b) in relation to the present study. In contrast, 
the mean size of the individuals in the Ubatuba population $(17.70 \mathrm{~mm})$ was larger than in the present study $(14.70 \mathrm{~mm})$, because $P$. diogenes in Armação of Itapocoroy showed a more evident skewness in the size frequency distribution. In both populations, the smallest individuals escape the fishing nets and inflate the smallest size classes. The stronger skewness in the size distribution of $P$. diogenes in Armação of Itapocoroy in comparison to Ubatuba probably evidence of the stronger over fishing in the former area.

Hermit crabs have variable patterns for the relationship between sex ratio and crab size (WenNer 1972). Petrochirus diogenes at Armação of Itapocoroy presents the standard pattern, with females dominating the smallest and males the largest size classes. Another population of this species at a northern site in Ubatuba also presented this pattern (BERTINI \& FRANSOZO 2000a). This may evidence the standard pattern of sex ratio (sensu WENNER 1972) is a species-specific instead of a population-specific characteristic. In fact, this pattern is quite dependent on the population size structure, characterized by males being larger than females. According to WENNER (1972), this pattern may be caused by a faster growth of males in relation to females. Despite this possibility, there is no information on growth rates of males and females for this species to reinforce this assumption. On the other hand, lack of juveniles (individuals smaller than the smallest ovigerous female $-19.0 \mathrm{~mm}$ ) and small size individuals in the samples may prevent further discussions on this subject once the pattern may change considerably if these individuals would be collected by the sampling procedure employed in the present study and in the study conducted by BERTINI \& FRANSOZO (2000a). Another possibility to explain the lack of small-sized sexually differentiated individuals in these two studies may be the habitat partitioning between them and the mature individuals. However, there are no data to support this hypothesis.

According to BERTINI \& Fransozo (2000a) and TURRA \& LeITE (2000), hermit crabs may have continuous or seasonal reproductive patterns. TURRA \& LEITE (2000) revealed that continuous reproduction is markedly more common in tropical waters but that seasonal reproduction is an important strategy in tropical and temperate regions. This is reinforced by $P$. diogenes, which presents a seasonal reproductive period in both tropical (BERTINI \& FRANSOZO 2000a) and subtropical (present study) waters. It is important to note that these two populations have coincident peaks of ovigerous females between February and April and absence or low number in the rest of the year. Once temperature optimum may be associated with peaks of reproduction in this species as exposed above, the depth where reproduction takes place is supposed to vary between populations of this species in a latitudinal gradient.

Isometry was recorded between cephalothoracic length and width in this population of $P$. diogenes as well as for the relationships between shield length and width in another population of this species (BERTINI \& FRANSOZO 2000b) and in Dardanus insignis (FERNANDES-GÓES \& FRANSOZO 2000) both in Ubatuba region. However, a sympatric population of $D$. insignis at Armação of Itapocoroy showed positive allometry between cephalothoracic length and width (BRANCO et al. 2002). Variation in the allometric patterns was also recorded for the relationship between

Revta bras. Zool. 19 (4): $1043-1051,2002$ 
cephalothoracic length and crab weight. Isometry was recorded in the study population and for $D$. insignis (shield length vs. shell weight -FERNANDES-GóES \& FRANSOZO 2000) in Ubatuba region, while BRANCO et al. (2002) recorded a negative allometry between these variables for $D$. insignis at Armação of Itapocoroy. This variability in allometric patterns between species and populations reinforce the plasticity of crab dimensions proposed by BLACKSTONE (1985). The negative allometry between crab size/weight and shell weight indicates that larger/heavier crabs are using proportionally lighter shells than smaller/lighter crabs. Once shell size and weight are generally well correlated (TURRA \& LEITE 2001, 2002), one may argue that larger crabs are using proportionally smaller shells. This supports the hypothesis that large hermit crab individuals, and even species, are under stronger shell limitation than smaller ones (SPIGHT 1985).

\section{REFERENCES}

ASAKURA, A. 1987. Preliminary observations on the offshore mass migration of the sand-dwelling hermit crab, Diogenes nitidimanus Terao (Crustacea: Decapoda: Anomura). Jour. Ethol., Tokyo, 5: 207-209.

Asakura, A. \& T. Kikuchi. 1984. Population ecology of the sand dwelling hermit crab, Diogenes nitidimanus Terao 2. Migration and life history. Publ. Amakusa Mar. Biol. Lab. 2: 109-123.

Bertinl, G. \& A. Fransozo. 1999a. Spatial and seasonal distribution of Petrochirus diogenes (Anomura. Diogenidae) in the Ubatuba Bay, São Paulo, Brazil. Iheringia, Sér. Zool., Porto Alegre, 86: 145-150

.1999b. Relative growth of Petrochirus diogenes (Linnaeus, 1758) (Crustacea, Anomura, Diogenidae) in the Ubatuba region, São Paulo, Brazil. Rev. Brasil. Biol., Rio de Janeiro, 59 (4): 617-625.

.2000a. Population dynamics of Petrochirus diogenes (Crustacea, Anomura, Diogenidae) in the Ubatuba region, São Paulo, Brazil, p. 331-342. In: J.C. von Vaupel Klein \& F. Schram (Eds).

The biodiversity crisis and Crustacea. Balkema, Rotterdam, A. A. Balkema, 840p.

- 2000b. Patterns of shell utilization in Petrochirus diogenes (Decapoda, Anomura, Diogenidae) in the Ubatuba region, São Paulo, Brazil. Jour. Crustacean Biol., Seminole, 20 (3): 468-473.

BLACKStone, N.W. 1985. The effects of shell size and shape on the growth and form in hermit crabs Pagurus longicarpus. Biol. Bull., Woods Hole, 168: 75-90.

Branco, J.O.; A. Turra \& F.X. Souto. 2002. Population biology and growth of the hermit crab Dardanus insignis at Armação do Itapocoroy, soutern Brazil. Jour. Mar. Biol. Ass. U.K. 82 (4): 597-604.

Branco, J.O.; M.J. Lunardon-Branco; A.C. Peret; F.X. Souto; R. Schvettzer \& W.G. Vale. 1998. Associações entre macroinvertebrados e peixes demersais na Armação do Itapocoroy, Penha, SC, Brasil. Braz. Arch. Biol. Technol., Curitiba, 41 (2): 268-277.

Coelho, P.A. \& M. Ramos-Porto. 1987. Sinopse dos crustáceos decápodes brasileiros (famílias Callianassidae, Callianeidae, Upogebiidae, Parapaguridae, Paguridae, Diogenidae). Trab. Oceanogr., Recife, 19: 27-53.

FERnANDES-Góes, L.C. \& A. Fransozo. 2000. Relative growth of the hermit crab Dardanus insignis (Saussure, 1858) (Decapoda, Anomura, Diogenidae) from Ubatuba region, SP, Brazil. Naturalia, Rio Claro, 25: 67-76.

Forest, J \& M. DE Saint Laurent. 1967. Campagne de la Calypso au large des cotes Atlantiques de l'Amérique du sud (1961-1962) I. 6. Crustacés Décapodes: Pagurides. Ann. Inst. Óceanogr., Paris, 5 (2): $47-169$.

FOTHERINGHAM, N. 1975. Structure of seasonal migrations of the littoral hermit crab Clibanarius vittatus (Bosc). Jour. Exp. Mar. Biol. Ecol., Amsterdam, 18: 47-53. 
Gasparinl, J.L. \& S.R. Floeter. 1999. The giant hermit crab Petrochirus diogenes (Linnaeus, 1758) (Crustacea, Anomura) maximun size. Nauplius, Rio Grande, 7: 185-186.

Hazlett, B.A. 1981. The behavioral ecology of hermit crabs. Ann. Rev. Ecol. Syst., Stanford, 12: 1-22.

KellogG, C.W. 1977. Coexistence in a hermit crab ensemble. Biol. Bull., Woods Hole, 153: 133-144.

Manjón-Cabeza, M.E. \& J.E. García-Raso. 1998. Structure and evolution of a decapod crustacean community from the coastal detritic bottoms of Barbate (Cadiz, Southern Spain). Jour. Nat. Hist., London, 32: 1619-1630.

Mantelatto, F.L.M. \& A. Fransozo. 1999. Characterization of the physical and chemical parameters of Ubatuba Bay, northern coast of São Paulo State, Brazil. Rev. Brasil. Biol., Rio de Janeiro, 59 (1): 23-31.

MartineZ-Iglesias, J.C. \& J.E. García-RASO. 1999. The crustacean decapod communities of the coral reefs from southwestern Caribbean sea of Cuba: species composition, abundance and structure of the communities. Bull. Mar. Sci., Miami, 65 (2): 539-557.

Mello, G.A.S. 1999. Manual de Identificação dos Crustacea Decapoda do Litoral Brasileiro: Anomura, Thalassidinea, Palinuridea, Astacidea. São Paulo, Plêiade/FAPESP, 551p.

Negreiros-Fransozo, M.L.; A. Fransozo; F.L.M. Mantelatto; M.A.A. Pinheiro \& S. Santos. 1997. Anomuran species (Crustacea, Decapoda) and their ecological distribution at Fortaleza Bay sublittoral, Ubatuba, São Paulo, Brazil. Iheringia, Sér. Zool., Porto Alegre, 83: 187-194.

Provenzano Jr., A.J. 1968. The complete larval development of the West Indian hermit crab Petrochirus diogenes (L.) (Decapoda, Diogenidae) reared in the laboratory. Bull. Mar. Sci., Miami, 18 (1): 143-181.

Rebach, S. 1978. The role of celestial cues in short range migration of the hermit crab, Pagurus longicarpus. Anim. Behav., London, 26: 835-842.

- 1981. Use of multiple cues in short-range migrations of crustacea. Amer. Mid. Nat., Notre Dame, Indiana, 105: 168-180.

Rieger, P.J. 1997. Os "ermitões" (Crustacea, Decapoda, Parapaguridae, Diogenidae e Paguridae) do litoral brasileiro. Nauplius, Rio Grande, 5 (2): 99-124.

Spight, T.M. 1985. Why small hermit crabs use large shells? Res. Pop. Ecol., Tokyo, 27: 39-54.

TURRA, A. \& F.P.P. Leite. 2000. Population biology and growth of three sympatric intertidal hermit crabs in south-eastern Brazil. Jour. Mar. Biol. Assoc. UK 80: 1061-1069.

- 2001. Shell utilization patterns of a tropical rocky intertidal hermit crab assemblage. I. the case of Grande Beach. Jour. Crustacean Biol., Seminole, 21 (4): 393-406.

2002. Shell utilization patterns of a tropical intertidal hermit crab assemblage. Jour. Mar. Biol. Assoc. UK 82: 97-107.

Wenner, A.M. 1972. Sex ratio as a function of size in marine crustacea. Amer. Nat., Chicago, 106: 321-350.

ZAR, J. H. 1996. Biostatistical Analysis. New Jersey, Prentice-Hall, 718p.

Received in 13.III.2002; accepted in 08.X.2002. 